$1-1-1965$

\title{
A Comparison of three breeds of rams as sires of market lambs
}

C. J. Cunningham

Follow this and additional works at: https://researchrepository.wvu.edu/ wv_agricultural_and_forestry_experiment_station_bulletins

\section{Digital Commons Citation}

Cunningham, C. J., "A Comparison of three breeds of rams as sires of market lambs" (1965). West Virginia Agricultural and Forestry Experiment Station Bulletins. 505.

https://researchrepository.wvu.edu/wv_agricultural_and_forestry_experiment_station_bulletins/470 @ WVU. It has been accepted for inclusion in West Virginia Agricultural and Forestry Experiment Station Bulletins by an authorized administrator of The Research Repository @WVU. For more information, please contact ian.harmon@mail.wvu.edu. 
West Virginia University Libraries 


Of Three Breeds Of Rams As Sires Of Market Lambs

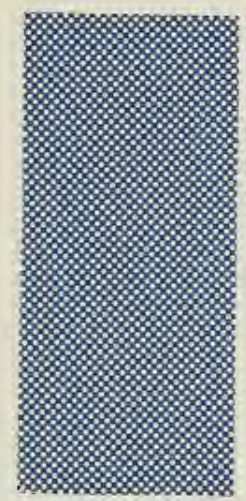

April 1965 Bulletin 505

t Virginia University Agricultural Experiment Station 
West Virginia University

Agricultural Experiment Station

College of Agriculture, Forestry, and Home Economics

A. H. VanLandingham, Director Morgantown 


\title{
A COMPARISON OF THREE BREEDS OF RAMS AS SIRES OF MARKET LAMBS
}

\author{
C. J. Cunningham \\ B. W. Wamsley \\ J. A. Welch \\ J. O. Heishman
}




\section{THE AUTHORS}

C. J. Cunningham is Station Animal Husbandman in charge of Reymann Vemorial Farms Substation; B. W. Wamsley is State Extension Animal Husbandry Specialist; J.A. Welch is Professor of Animal Husbandry and Station Animal Husbandman; and J. 0. Heishman is Associate Station Animal Pathologist, Reymann Vemorial Farms Substation.

\section{ACKNOWLEDGMENT}

Wuch of the information contained in this bulletin is based on analysis of data presented by B. W. Wamsley for his thesis as part of the requirements for the Master of Science degree. 


\section{A Comparison of Three Breeds}

\section{Of Rams As Sires of Market Lambs}

\section{J. Cunningham, B. W. Wamsley, J. A. Welch, and J. O. Heishman}

When this study began, yearling ewes for flock replacements were being brought into West Virginia from the northwestern United States. These sheep were chiefly crosses of Sulfolk, Hampshire, or Columbia rams on range type ewes. The question was which of the more popular, readily available breeds of rams used in this region, e.g., Dorset, Hampshire, or Corridale, could be expected to give the best return in terms of market lambs when crossed with these Northwestern ewes.

Rae $[1](1952)$ in a comprehensive review of numerous experimental comparisons of cross breeding of sheep for lamb and mutton production in differentparts of the world concluded that different markets vary widely in their carcass weight and quality requirements. For this reason, the comparison of breeds of sires for meat production was difficult to generalize. Also, information regarding the comparative performance of Dorsets, one of the more popular breeds in West Virginia in 1952, was generally lacking in experimental comparisons made in the United States.

\section{EXPERIMENTAL PROCEDURE}

This study was conducted at Reymann Memorial Farms, a substation of the West Virginia University Agricultural Experiment Station, located at Wardensville. Research was conducted from 1953 to 1958.

The 99 Northwestern ewes used in the experiment were selected from 102 lambs purchased from California in 1951. They were bred that year to Southdown rams. Most unsound ewes were identified through this. early breeding before they were placed on experiment as yearlings. 
Each ram in the experiment was used only one year. Additional rams purchased each year were unrelated to those used previously. Rams of the highest quality obtainable of each breed were purchased in the West Virginia Purebred Ram Sales. Occasionally suitable rams of one or more breeds were not avalable in these sales, and it was necessary to obtain them through other channels.

During the last three years of the study, the breeding program was designed so that ewe replacements tept from the three previous years were grouped with the Northwestern ewes to be bred to Hampshire and Dorset rams. The addition of these ewes necessitated the use of extra rams of these two breeds. The number of rams of the three breeds used each year is shown in Table 1.

\section{TABLE 1}

Number of Each Breed of Ram Used Each lear and Total

$\begin{array}{lccccccc}\text { Breed } & 1952 & 1953 & 1954 & 1955 & 1956 & 1957 & \text { Total } \\ \text { Hampshire } & 1 & 1 & 1 & 1 & 3 & 2 & 9 \\ \text { Dorset } & 1 & 1 & 1 & 2 & 2 & 3 & 10 \\ \text { Corriedale } & 1 & 1 & 1 & 1 & 1 & 1 & 6\end{array}$

To initiate the study, the ewes were divided randomly into three groups. Flock 1 was mated to a Corriedale ram, flock 2 to a Dorset ram, and flock 3 to a Hampshire ram. In the succeeding two years, the breeding plan was rotated so that in the course of three years each group of ewes was mated to a ram of each breed. At the beginning of the fourth breeding season, the flock was culled on the basis: of past productivity and soundness and randomly re-allocated into three groups of approximately 20 ewes each. The groups again were rotated so that each group was mated to a ram of each breed.

Each year the different groups werepasture bred, allowing a twomonth breeding season beginning in early September. After breeding. the three groups of ewes were put together and treated as one flock. Lambs were born in a barn and were weighed and ear-tagged at birth. The lambs were docked and castrated when 1 to 2 weeks old. All lambs were creep fed grain until the ewes were turned to pasture, except in 1953 and 1954 when all lambs were creep fed until marketed or weaned.

Parasite control measures consisted of feeding free choice a mixture of one part phenathiazine and nine parts salt. In addition to this, each ewe received 25 grams of phenothiazine before going to pasture and again in the fall about two weeks before breeding. When necessary, all sheep were sprayed to control external parasites. 
Lambs were marketed each year in two drafts. The first draft was made about June 15 when all were weighed and graded as slaughter lambs. At this time, wether lambs weighing 80 pounds or more and grading choice or above were marketed. The remaining lambs were weighed and graded again one month later and either marketed or weaned. Each year, however, approximately one third of the top ewe lambs were retained for flock replacements.

The grading of the lambs was done by a committee consisting of a University staff member, a Reymann llemorial Farms staff member, and an "official" lamb grader, employed by the West Virginia Live. stock Marketing Association. Federal standards for grading of slaughter lambs were used. The lambs were graded to the nearest whole grade and assigned a numerical value. Values assigned were: prime and choice grades-1; good-2; medium-3; plain-4; and cull-5. Each committee member scored each lamb individually and the average of the scores to the nearest grade was the lamb's final grade.

Different lamb traits studied were recorded on IBM cards. All records were adjusted for differences due to type of birth (single or multiple), sex, and year of birth by least squares multiple regression. Analysis of variance then was used to test for difference among breeds of ram (Snedecor [2] 1959).

TABLE 2

Number of Ewes Exposed to Each Breed of Ram Each Year

$\begin{array}{lccccccc}\text { Breed of Sire } & 1952 & 1953 & 1954 & 1955 & 1956 & 1957 & \text { Total } \\ \text { Corriedale } & 31 & 28 & 27 & 21 & 18 & 13 & 138 \\ \text { Dorset } & 30 & 30 & 30 & 19 & 17 & 17 & 143 \\ \text { Hampshire } & 31 & 30 & 26 & 20 & 18 & 15 & 140\end{array}$

TABLE 3

Number of Lambs Born by Breed of Sire and Year

$\begin{array}{lccccccc}\text { Breed of Sire } & 1953 & 1954 & 1955 & 1956 & 1957 & 1958 & \text { Total } \\ \text { Corriedale } & 39 & 51 & 51 & 34 & 38 & 23 & 236 \\ \text { Dorset } & 40 & 51 & 35 & 19 & 26 & 30 & 201 \\ \text { Hampshire } & 44 & 45 & 47 & 38 & 27 & 27 & 228\end{array}$

\section{TABLE 4}

Number of Lambs Weaned by Breed of Sire and Year

$\begin{array}{lccccccc}\text { Breed of Sire } & 1953 & 1954 & 1955 & 1956 & 1957 & 1958 & \text { Totol } \\ \text { Corriedale } & 37 & 47 & 49 & 33 & 29 & 17 & 212 \\ \text { Dorset } & 34 & 43 & 32 & 16 & 22 & 25 & 172 \\ \text { Hampshire } & 37 & 37 & 35 & 28 & 24 & 23 & 184\end{array}$




\section{RESULTS AND DISCUSSION}

\section{Adjustment of Data}

The data on all lambs were adjusted to a single male, common year basis in order to make valid comparisons of breeds of sire for market lamb production. The type of birth (single or multiple) adjustments show a single lamb averaged $1.91 \mathrm{lbs}$. heavier at birth than a lamb born as a twin or triplet. Nale lambs averaged .69 lb. heavier than females. The lambs that were raised as singles gained $.07 \mathrm{lb}$. more per day and graded .54 of a grade higher than lambs raised as twins. Wether lambs gained $.03 \mathrm{lb}$. more per day and graded .02 of a grade higher than ewes. As all groups of ewes were composed of the same general type and bred to all ram groups no adjustments were made for age and type.

These results are in agreement with factors for adjustments found by Carter et al. [3] (1958) which showed that male lambs averaged $.29 \mathrm{lb}$. heavier at birth and gained $.03 \mathrm{lb}$. more per day than females. Single lambs were $1.87 \mathrm{lbs}$. heavier at birth and gained $.07 \mathrm{lb}$. per day faster, on the average, than twins.

The adjusted averages of the different lamb traits studied are shown by breeds of ram in Table 5 .

\section{TABLE 5}

Average Adjusted ${ }^{\mathrm{a}}$ Birth Weight, Daily Gain and Per Cent Mortality by Breed of Sire

\section{Breed of Sire}

Corriedale

Dorset

Hampshire

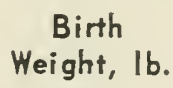

9.5

9.2

10.1

Daily
Gain, Ib.
.523
.525
.536

Slaughter
Grade
2.00
1.74
1.65

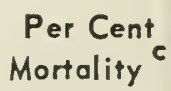

10.2

13.4

20.2

a. Records were adjusted to a single, male, common year basis

b. Grade code: prime and choice 1.00; good 2.00; medium 3.00; plain 4.00 ; cull 5.00

c. Per cent mortality of lambs from birth to weaning, including stillbirths

\section{Lamb Crop}

Variations in the number of lambs born per ewe by breed of sire and the number of lambs weaned per ewe by breed of sire were both highly significant $(P<.01)$ among the breeds of ram studied. The Corriedale rams were mated to a total of 138 ewes. These ewes 
dropped 1.62 lambs per ewe exposed and weaned 1.45 lambs (Appen. dix, Tables 1 and 2). The number of lambs born and the number of lambs weaned per ewe exposed to Corriedale rams are significantly $(\mathrm{P}<.01)$ greater than ewes exposed to the Dorset rams. When the Corriedale-sired lambs are compared with the Hampshire-sired lambs, the number of lambs born per ewe exposed is not significantly dif. ferent. However, the difference between the number of lambs weaned by ewes exposed to the two breeds is significant at the 5 per cent level. These findings are in agreement with Gorman et al. $[4]$ (1942). In their studies, the ewes exposed to Corriedale rams gave birth to a higherper cent of lambs than did the ewes exposed to other breeds of ram studied.

The Hampshire rams were mated to 140 ewes. The ewes dropped 1.56 lambs per ewe exposed and weaned 1.22 lambs (Appendix, Tables 1 and 2). The Dorset rams were mated to 143 ewes. The ewes dropped 1.32 lambs per ewe exposed and weaned 1.10 lambs (Appendix, Tables 1 and 2). When comparing the lamb crop sired by the Hampshire and Dorset rams, the number of lambs born per ewe exposed to the Hampshire is significantly greater at the 5 per cent level. However, analysis of variance shows that the difference in the number of lambs weaned per ewe by the ewes exposed to the two breeds was not significant $(\mathrm{P}<.05)$.

\section{Mortality}

Difference in the percentage of lamb mortality, from birth to weaning, was not significant among breeds of ram studied. The Corriedale-sired lambs, however, did have a lower mortality rate than did either the Hampshire- or Dorset-sired lambs. This difference in mortality rate approached the 5 per cent probability level (Appendix, Table 3).

The Corriedale rams sired a total of 236 lambs during the sixyear period, 212 of which were marketed or weaned, giving a mortality rate of 10.2 per cent, the lowest of the three breeds studied. The Dorset rams sired 201 lambs. Only 172 of these lambs reached market or weaning age-a mortality rate of 13.4 per cent. In turn, the Hampshire rams sired 228 lambs of which 184 reached market age for a mortality rate of 20.2 per cent, the highest of the three breeds. These findings are in agreement with Gorman et al. [4] (1942). In their study, ewes with Corriedale-sired lambs raised a higher percentage of lambs, per 100 ewes, than did the ewes with lambs sired by other breeds of ram used in the study.

Analysis of variance (Appendix, Table 3) shows no significant difference in lamb mortality among breeds of sire even though the 
average per cent mortality shows a wide range among breed averages. When the mortality rate is examined by breed of sire by year, we find a wide variation within the breeds. The Corriedale-sired lambs had a low mortality rate of 2.6 per cent in 1954 and a high rate of 26.7 per cent in 1958. Likewise the Hampshire-sired lambs from one ram had a mortality of 0 per cent in 1957 compared to 26.9 per cent in the lambs of one Hampshire ram in 1956.

\section{Birth Weight}

The adjusted mean birth weights for the lambs by breed of sire were $10.1 \mathrm{lbs}$. for the Hampshire-sired lambs; $9.5 \mathrm{lbs}$. for the Corriedale-sired lambs; and 9.2 lbs. for the Dorset-sired lambs. The variation in mean birth weights among the lambs sired by the different breeds of ram is highly significant. Analysis of variance (Appendix, Table 4) shows that the Hampshire-sired lambs were significantly $(P<.01)$ heavier at birth than either the Corriedale- or Dorset-sired lambs. The difference of $.3 \mathrm{lb}$. in birth weight between the Corriedale- and Dorset-sired lambs approached the 5 per cent probability level.

These results are in agreement with the findings of Carter et al. [3] (1958). Their experiments showed that Hampshire-sired lambs were $.3 \mathrm{lb}$. heavier at birth than lambs sired by Corriedale and $.7 \mathrm{lb}$. heavier than the Dorset-sired lambs. Other investigations by Miller [5] (1935), Hultz [6] (1935), Neville et al. [7] (1938), and Butcher [8] (1959) also found that Hampshire-sired lambs wereheavier at birth than lambs sired by other breeds of ram studied.

\section{Average Daily Gain}

The variation in average daily gain of the lambs was not significant among the three breeds of sires studied, however, the differences did approach the 5 per cent level of significance (Appendix, Table 5). Hampshire-sired lambs grew somewhat faster than did the Dorsets or Corriedales. The average daily gain, from birth to weaning, was virtually identical for all groups. This work is in agreement with the findings of Sabin et al. [6] (1962). Their experiment with Hampshireand Dorset-sired crossbred lambs showed that breed of sire had no significant influence on the growth rate of the lambs. However, Hampshire-sired lambs in their test were slightly superior in performance to Dorsets.

It should be noted that variation in rate of gain among lambs sired by different rams of a breed can be large. During 1956, 1957, and 1958 this experiment necessitated the use of more than one sire each year in the Hampshire and Dorset breeding program (Appendix, Table 5). In 1956 Dorset sire number 4 produced lambs that gained 
$.55 \mathrm{lb}$. per day, while Dorset sire number 5 produced lambs that gained $.61 \mathrm{lb}$. per day. In 1958 the lambs produced by the three different Dorset rams used showed a variation in rate of gain from a low of .44 lb. per day to a high of $.50 \mathrm{lb}$. per day. In 1957 the three Hampshire rams sired lambs that gained at the rate of $.59 \mathrm{lb} ., .51 \mathrm{lb}$, and $.47 \mathrm{lb}$, respectfully. In 1958 again there was a difference in rate of gain by Hampshire-sired lambs. Lambs by Hampshire sire number 9 gained $.34 \mathrm{lb}$. per day, while lambs by sire number 8 gained $.40 \mathrm{lb}$. per day. Differences among sires were not tested for significance because in most instances yearly difference was confused by the performance of individual sires.

\section{Slaughter Grade}

The lambs sired by Hampshire rams showed the highest slaughter grade, averaging good plus (1.6) (Appendix, Table 6). The Dorsetsired lambs also graded an average of good plus (1.7), followed by the Corriedales grading an average of good (2.0). The average grades of the Hampshire- and Dorset-sired lambs were significantly $(P<.01)$ higher than that of the Corriedale-sired lambs. The lambs by the Hampshire rams were also somewhat superior in grade to the Dorsets, but the difference was not significant. Analysis of variance and grade codes for thelambs by the different breeds of sires is given in Appendix, Table 6 . 


\section{CONCLUSION}

When making a comparion of the different breeds of rams as sires of market lambs, a number of factors must be considered. The selection of the breed of ram may be governed by the size of carcass demanded, feed and pasture available, type of ewe used in the flock, and the availability of the breed desired. The three breeds of rams used in this comparison are available to producers in this area. IIampshires and Dorsets are available in larger numbers than Corriedales. Economically valuable traits also must be considered in selecting a sire for market lamb production. About three-fourths of the income from the sheep industry comes from the sale of lambs for meat, therefore, pounds of lamb produced per ewe bred should receive greatest emphasis (Terrill $[10] 1961$ ). The traits which affect the pounds of lamb produced are the number of lambs born, mortality from birth to weaning, birth weight, and daily rate of gain. Although pounds of lamb produced per ewe is closely related to income, the quality of the lambs must not be forgotten. Slaughter grade also plays an im. portant role in the gross income from market lambs (Winters [11]1946).

The lambs produced from the mating of Hampshire rams on Vorthwestern ewes were heavier at birth, gained faster, and graded higher at market age than werelambs sired by either the Corriedale or Dorset rams. Ilowever, the mortality rate of the IIampshire-sired lambs, from birth to weaning, was the highest among the three breeds studied. Hampshire-sired lambs would be expected to reach the desired market weight with a better grade earlier than lambs sired by either the Corriedale or Dorset rams but fewer lambs per ewe could be expected.

The lambs sired by the Dorset rams on Northwestern ewes were smallest at birth but their rate of gain was equal to that of the Corriedales. Their live slaughter grade was above that of the Corriedalesired lambs and Was surpassed only by the Hampshire-sired lambs. The number of lambs born per Dorset ewe mated was low, due in part to the use of a ram with low fertility during one year of the study. Lamb mortality from birth to weaning for the Dorset-sired lambs was less than IIampshire-sired but greater than Corriedale-sired lambs. Ewes mated to Corriedale rams would be expected to wean more pounds of lamb per ewe bred than ewes mated to either Hampshire or Dorset rams. The low slaughter grade of the Corriedales would, however, affect their gross income. Conversely, the ewes mated to the Dorset rams weaned the least pounds of lamb per ewe bred, but the lambs graded one-third of a grade higher than the Corriedales, giving them an advantage at market time. 
Differences among the three breeds of rams as sires of market lambs are small, and the choice of any one breed may depend on its availability and the producer's personal preference. However, ad. vantages can always be gained by using superior sires of any breed.

\section{SUMMARY}

A study of the different traits of market lambs sired by three breeds of rams is reported. Northwestern ewes were mated to rams of the Corriedale, Dorset, and Hampshire breeds in a six-year study at the Reymann Vemorial Farms, a substation of the West Virginia University Agricultural Experiment Station. A total of 138 ewes was exposed to Corriedale rams; 144 to the Dorsets; and 140 to the Hampshire rams. Comparisons were made of the number of lambs born per ewe mated, number of lambs weaned per ewe mated, birth weight, rate of gain, and live slaughter grade of lambs by breed of sire.

The data on lambs were adjusted for difference due to sex, type of birth or rearing, and year of birth. The adjustments were made to convert each lamb's record to a single, male, and common year basis so that valid comparisons among breeds of ram could be made.

Results of the different lamb traits studied were:

1. Ewes mated to the Corriedale rams weaned the largest number of lambs per ewe mated (1.53), followed by the Hampshire-sired lambs (1.31), and Dorset-sired lambs (1.20).

2. The rank of adjusted birth weight of the lambs by breed of ram were: Hampshire $10.1 \mathrm{lbs}$, Corriedale $9.5 \mathrm{lbs}$, and the Dorsetsired lambs $9.2 \mathrm{lbs}$.

3. In the adjusted average daily rate of gain, there was little difference among the breeds studied.

4. In live slaughter grade the Hampshire-sired lambs were superior to the other two breeds and graded an average of good plus (1.6), followed closely by the Dorsets, also grading good plus (1.7), and the Corriedale-sired lambs graded average good (2.9). 

Appendix 


\section{TABLE 1}

Number of Lambs Born Per Ewe Bred by Breed of Sire and Year

\begin{tabular}{|c|c|c|c|c|c|c|}
\hline Year & $\begin{array}{l}\text { Sire } \\
\text { No. }\end{array}$ & $\begin{array}{c}\text { Corriedale } \\
\text { Mean }\end{array}$ & $\begin{array}{l}\text { Sire } \\
\text { No. }\end{array}$ & $\begin{array}{c}\text { Hampshire } \\
\text { Mean }\end{array}$ & $\begin{array}{l}\text { Sire } \\
\text { No. }\end{array}$ & $\begin{array}{l}\text { Dorset } \\
\text { Mean }\end{array}$ \\
\hline 1953 & 1 & $1.16(31)^{\mathrm{a}}$ & 1 & $1.37(31)^{\mathrm{a}}$ & 1 & $1.22(30)^{\mathrm{a}}$ \\
\hline 1954 & 2 & $1.76(28)$ & 2 & $1.43(30)$ & 2 & $1.72(30)$ \\
\hline 1955 & 3 & $1.85(27)$ & 3 & $1.69(26)$ & 3 & $1.05(30)$ \\
\hline 1956 & 4 & $1.56(21)$ & 4 & $1.85(20)$ & 4 & $1.43(10)$ \\
\hline 1956 & & $\ldots \ldots$ & & $\ldots \ldots$ & j & $0.37(9)$ \\
\hline 1957 & 5 & $2.06(18)$ & 5 & $1.40(9)$ & 6 & $1.13(9)$ \\
\hline 1957 & & $\ldots . .$. & 6 & $1.92(4)$ & 7 & $1.82(8)$ \\
\hline 1957 & & . . . . & 7 & $1.05(5)$ & & $\ldots .$. \\
\hline 1958 & 6 & $1.62(13)$ & 8 & $1.82(\mathrm{~S})$ & 8 & $1.79(6)$ \\
\hline 1958 & & $\ldots . .$. & 9 & $1.62(7)$ & 9 & $1.25(6)$ \\
\hline 1958 & & $\ldots . .$. & & $\ldots . .$. & 10 & $1.96(5)$ \\
\hline \multirow{2}{*}{\multicolumn{2}{|c|}{$\begin{array}{l}\text { Total or } \\
\text { Average }\end{array}$}} & & & & & \\
\hline & & $1.62(138)^{a}$ & & $1.56(140)^{\mathrm{a}}$ & & $1.32(143$ \\
\hline
\end{tabular}

$$
\text { Analysis of Variance }{ }^{b}
$$

Source

D F

S S

MS

Total 420 28.5434

Breeds

2

Sire

22

$$
0.7793
$$

0.3897

$6.57^{* *}$

Within

396

4.2597

0.1936

23.5044

0.0593

a Ewes bred to each breed of ram per year

b lleans were transformed to $\sqrt{\text { observe value }+1}$ for purposes of analysis of variance

** Significant at the one per cent level 


\section{TABLE 2}

Number of Lambs Weaned Per Ewe Bred by Breed of Sire and Year

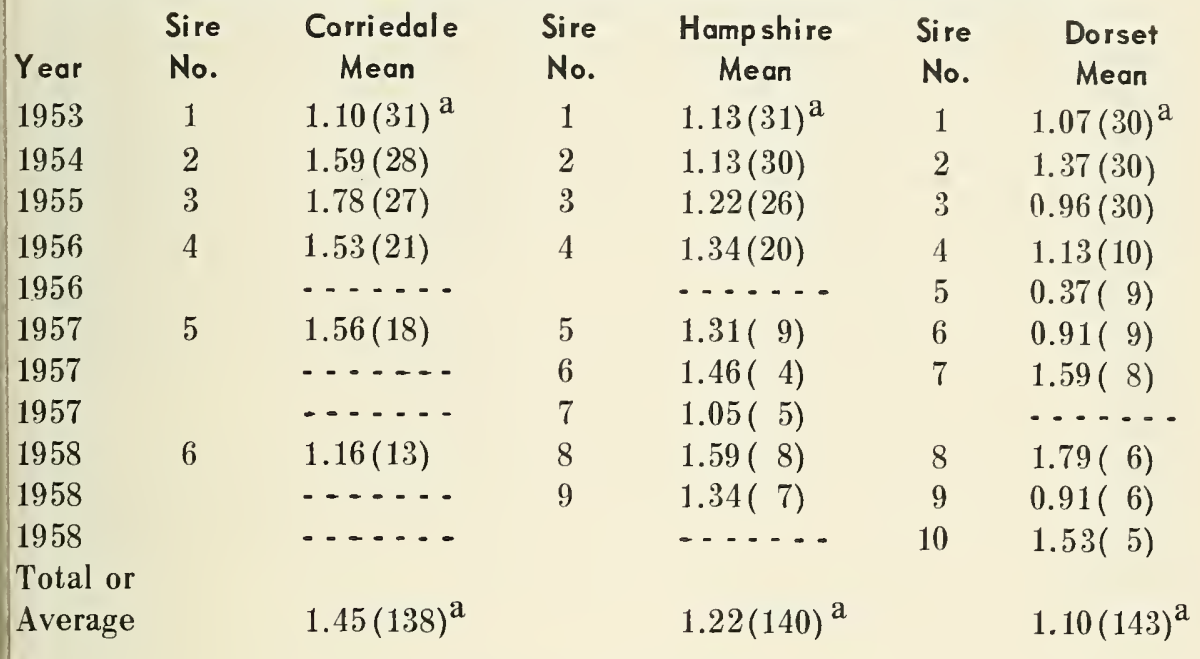

Analysis of Variance $b$

\begin{tabular}{lrrrc} 
Source & D F & \multicolumn{1}{c}{ S S } & M S & F \\
Total & 420 & 30.0146 & & \\
Breeds & 2 & .9232 & 0.4616 & $6.98^{* *}$ \\
Sire & 22 & 2.8782 & 0.1353 & \\
Within & 396 & 26.2132 & 0.0661 &
\end{tabular}

a Ewes bred to each breed of ram per year

b Means were transformed to $\sqrt{\text { observe value }+1}$ for purposes of analysis of variance

** Significant at the one per cent level 


\section{TABLE 3}

Per Cent Lamb Mortality by Breed of Sire by Year and Total

\begin{tabular}{|c|c|c|c|c|c|c|}
\hline Year & $\begin{array}{l}\text { Sire } \\
\text { No. }\end{array}$ & $\begin{array}{l}\text { Corriedale } \\
\text { Per cent }\end{array}$ & $\begin{array}{l}\text { Sire } \\
\text { No. }\end{array}$ & $\begin{array}{l}\text { Hampshire } \\
\text { Per cent }\end{array}$ & $\begin{array}{l}\text { Sire } \\
\text { No. }\end{array}$ & $\begin{array}{l}\text { Dorset } \\
\text { Per cent }\end{array}$ \\
\hline 1953 & 1 & $10.2(25)^{\mathrm{a}}$ & 1 & $18.7(29)^{\mathrm{a}}$ & 1 & $11.3(27)^{\mathrm{a}}$ \\
\hline 1954 & 2 & $9.9(26)$ & 2 & $23.9(27)$ & 2 & $20.4(29)$ \\
\hline 1955 & 3 & $3.1(27)$ & 3 & $25.3(22)$ & 3 & $5.8(22)$ \\
\hline 1956 & 4 & $2.6(20)$ & 4 & $26.9(20)$ & 4 & $17.4(9)$ \\
\hline 1956 & & $\ldots \ldots$ & & $\ldots .$. & 5 & $0(3)$ \\
\hline 1957 & 5 & $20.5(18)$ & 5 & $5.8(9)$ & 6 & $18.3(7)$ \\
\hline 1957 & & $\ldots \ldots$ & 6 & $21.5(4)$ & 7 & $10.7(8)$ \\
\hline 1957 & & $\ldots . .$. & 7 & $0(3)$ & & $\ldots \ldots$ \\
\hline 1958 & 6 & $26.7(10)$ & 8 & $10.7(8)$ & 8 & $0(6)$ \\
\hline 1958 & & $\ldots \ldots$ & 9 & $12.1(6)$ & 9 & $25.7(5)$ \\
\hline 1958 & & $\ldots \ldots$ & & $\ldots \ldots$ & 10 & $20.9(5)$ \\
\hline Total or & & & & & & \\
\hline Average & & $10.2(126)^{\mathrm{a}}$ & & $13.4(128)^{\mathrm{a}}$ & & $20.2(121)^{\mathrm{a}}$ \\
\hline
\end{tabular}

Analysis of Variance

$\begin{array}{lcccc}\text { Source } & \text { D F } & \text { S S } & \text { MS } & F \\ \text { Total } & 374 & 41.6220 & & \\ \text { Breeds } & 2 & 0.6545 & 0.3273 & 2.94^{b} \\ \text { Sires } & 22 & 1.9134 & 0.0869 & \\ \text { Error } & 350 & 39.0541 & 0.1115 & \\ \text { a Number of ewes lambing per year and total for the six-year period } \\ \text { b Not significant }\end{array}$




\section{TABLE 4}

Adjusted Birth Weight ${ }^{\text {a }}$ by Breed of Sire by Year and Totals

\begin{tabular}{|c|c|c|c|c|c|c|}
\hline Year & $\begin{array}{l}\text { Sire } \\
\text { No. }\end{array}$ & $\begin{array}{l}\text { Corriedale } \\
\text { Pounds }\end{array}$ & $\begin{array}{l}\text { Sire } \\
\text { No. }\end{array}$ & $\begin{array}{l}\text { Hampshire } \\
\text { Pounds }\end{array}$ & $\begin{array}{l}\text { Sire } \\
\text { No. }\end{array}$ & $\begin{array}{l}\text { Dorset } \\
\text { Pounds }\end{array}$ \\
\hline 1953 & 1 & $8.4(39)^{\mathrm{b}}$ & 1 & $9.3(44)^{b}$ & 1 & $8.1(39)^{b}$ \\
\hline 1954 & 2 & $9.1(51)$ & 2 & $10.2(45)$ & 2 & $9.3(53)$ \\
\hline 1955 & 3 & $9.5(51)$ & 3 & $9.7(47)$ & 3 & $10.1(35)$ \\
\hline 1956 & 4 & $10.4(34)$ & 4 & $10.5(38)$ & 4 & $9.0(15)$ \\
\hline 1956 & & $\ldots \ldots$ & & $\ldots \ldots$ & 5 & $8.8(4)$ \\
\hline 1957 & 5 & $10.5(38)$ & 5 & $10.9(13)$ & 6 & $8.7(11)$ \\
\hline 957 & & $\ldots \ldots$ & 6 & $11.1(8)$ & 7 & $9.4(15)$ \\
\hline 1957 & & $\ldots \ldots$ & 7 & $9.3(6)$ & & $\ldots . .$. \\
\hline 1958 & 6 & $9.7(23)$ & 8 & $10.4(15)$ & 8 & $9.5(11)$ \\
\hline 1958 & & $\ldots \ldots$ & 9 & $10.6(12)$ & 9 & $8.8(8)$ \\
\hline 1958 & & $\ldots \ldots$ & & $\ldots \ldots$ & 10 & $9.7(10)$ \\
\hline $\begin{array}{l}\text { otal or } \\
\text { verage }\end{array}$ & & $9.5(236)^{b}$ & & $10.1(228)^{b}$ & & $9.2(201)^{b}$ \\
\hline
\end{tabular}

Analysis of Variance

\begin{tabular}{lrrrc} 
Source & D F & \multicolumn{1}{c}{ S S } & M S & F \\
Total & 664 & 2045.2040 & & \\
Breeds & 2 & 83.6290 & 41.81 & $15.84^{* *}$ \\
Sire & 22 & 272.5530 & 12.39 & \\
Within & 640 & 1689.0220 & 2.64 &
\end{tabular}

a Birth weight adjusted to a single, male, common year basis

b Number of lambs per year and total for the six-year period ** Probability <.01 


\section{TABLE 5}

Adjusted Average Daily Gain ${ }^{\mathrm{a}}$ by Breed of Sire by Year and Total

\begin{tabular}{|c|c|c|c|c|c|c|}
\hline Year & $\begin{array}{l}\text { Sire } \\
\text { No. }\end{array}$ & $\begin{array}{l}\text { Corriedale } \\
\text { Pounds }\end{array}$ & $\begin{array}{l}\text { Sire } \\
\text { No. }\end{array}$ & $\begin{array}{c}\text { Hampshire } \\
\text { Pounds }\end{array}$ & $\begin{array}{l}\text { Sire } \\
\text { No. }\end{array}$ & $\begin{array}{l}\text { Dorset } \\
\text { Pounds }\end{array}$ \\
\hline 1953 & 1 & $.506(37)^{b}$ & 1 & $.535(37)^{b}$ & 1 & $.523(34)^{b}$ \\
\hline 1954 & 2 & $.528(47)$ & 2 & $.577(37)$ & 2 & $.551(43)$ \\
\hline 1955 & 3 & $.551(49)$ & 3 & $.597(35)$ & 3 & $.552(32)$ \\
\hline 1956 & 4 & $.540(33)$ & 4 & $.550(28)$ & 4 & $.557(12)$ \\
\hline 1956 & & $\ldots . .$. & & $\ldots . .$. & 5 & $.609(6)$ \\
\hline 1957 & 5 & $.505(29)$ & 5 & $.513(12)$ & 6 & $.482(9)$ \\
\hline 1957 & & $\ldots . .$. & 6 & $.592(6)$ & 7 & $.485(13)$ \\
\hline 1957 & & $\ldots \ldots$ & 7 & $.478(6)$ & & $\ldots .$. \\
\hline 1958 & 6 & $.456(17)$ & 8 & $.404(13)$ & 8 & $.444(11)$ \\
\hline 1958 & & $\ldots .$. & 9 & $.341(10)$ & 9 & $.502(6)$ \\
\hline 1958 & & $\ldots . .$. & & $\ldots .$. & 10 & $.450(8)$ \\
\hline $\begin{array}{l}\text { Total or } \\
\text { Average }\end{array}$ & & $.523(212)^{b}$ & & $.536(184)^{b}$ & & $.525(172)^{\mathrm{b}}$ \\
\hline
\end{tabular}

Analysis of Variance

$\begin{array}{lrrrr}\text { Source } & \text { D F } & \text { S S } & \text { M S } & \text { F } \\ \text { Total } & 567 & 3.5302 & & \\ \text { Breeds } & 2 & .0201 & .0101 & 2.46^{\mathrm{c}} \\ \text { Sire } & 22 & 1.2452 & .0566 & \\ \text { Within } & 543 & 2.2649 & .0041 & \end{array}$

a Average daily gains adjusted to a single, male, common year basis

b Number of lambs by sire per year and total for the six-year study

c Approaches significance at the .05 per cent level 


\section{TABLE 6}

Adjusted $^{\mathrm{a}}$ Live Slaughter Grade ${ }^{\mathrm{b}}$ by Sire by Year and Total

\begin{tabular}{|c|c|c|c|c|c|c|}
\hline & Sire & Corriedale & Sire & Hampshire & Sire & Dorset \\
\hline Year & No. & Av. Grade & No. & Av. Grade & No. & Av. Grade \\
\hline 1953 & 1 & $1.61(37)^{\mathrm{c}}$ & 1 & $1.51(37)^{\mathrm{c}}$ & 1 & $1.62(34)^{\mathrm{c}}$ \\
\hline 1954 & 2 & $1.58(47)$ & 2 & $1.13(37)$ & 2 & $1.33(43)$ \\
\hline 955 & 3 & $1.69(49)$ & 3 & $1.42(35)$ & 3 & $1.53(32)$ \\
\hline 956 & 4 & $2.82(33)$ & 4 & $1.66(28)$ & 4 & $1.50(12)$ \\
\hline 1956 & & $\ldots . .$. & & $\ldots . .$. & 5 & $2.88(4)$ \\
\hline 1957 & 5 & $2.13(29)$ & 5 & $1.80(12)$ & 6 & $2.49(9)$ \\
\hline 1957 & & $\ldots \ldots$ & 6 & $1.38(6)$ & 7 & $2.22(13)$ \\
\hline 957 & & $\ldots \ldots$ & 7 & $2.20(6)$ & & $\ldots . .$. \\
\hline 58 & 6 & $3.12(17)$ & 8 & $2.75(13)$ & 8 & $2.55(11)$ \\
\hline 58 & & $\ldots \ldots$ & 9 & $3.06(10)$ & 9 & $2.03(6)$ \\
\hline 58 & & $\ldots \ldots$ & & $\ldots .$. & 10 & $2.13(8)$ \\
\hline tal or & & & & & & \\
\hline verage & & $2.00(212)^{c}$ & & $1.65(184)^{\mathrm{c}}$ & & $1.74(172)^{\mathrm{c}}$ \\
\hline
\end{tabular}

Analysis of Variance

\begin{tabular}{lrrrr} 
Source & D F & \multicolumn{1}{c}{ S S } & M S & F \\
Total & 567 & 283.69 & & \\
Breeds & 2 & 13.48 & 6.74 & $16.44^{* *}$ \\
Sires & 22 & 146.00 & 6.64 & \\
Within & 543 & 224.21 & 0.41 &
\end{tabular}

a Slaughter grade adjusted to a single, male, common year basis

b Grade code: prime and choice 1.00; good 2.00; medium 3.00 ; plain 4.00 ; cull 5.00

c Number of lambs by sire per year and total for the period ** Probability $<.01$ 


\section{LITERATURE CITED}

1. Rae, A. L. 1952. Crossbreeding of Sheep. II. Crossbreeding for Lamb and Mutton Production. Animal Breeding Abst. 20: 287299.

2. Snedecor, G. W. 1959. Statistical Methods. Iowa State College Press.

3. Carter, R, C., C. M. Kincaid, J. A. Gaines and G. W. Litton. 1958. Breed of Ram for Spring Lamb Production. Va. Agr. Exp. Sta. Bull. 492.

4. Gorman, J. A., F. S. Hultz, R. L. Hiner, O. G. Hankins and D. A. Spencer. 1942. Crossbreeding for Lamb and Wool Production. Wyo. Agr. Exp. Sta. Bull. 254.

5. Miller, Robert F. 1935. Crossbreeding Investigations in the Production of California Spring Lambs. Calif. Agr. Exp. Sta. Bull. 598.

6. Hultz, F. S., J. A. Gorman and S. S. Wheeler. 1935. Crossbreeding with Hestern Ewes. Wyo. Agr. Exp. Sta. Bull. 210.

7. Neville, W. E., A. B. Chapman and A. L. Pope. 1958. Comparison of Lambs From Western Ewes and Sired by Rams of Four Down Breeds. Jour. An. Sci. 17: 763-773.

8. Butcher, R. L. 1959. Genetic Parameters of Birth Weight and 140-Day Weight in Lambs. Master's Thesis, West Virginia University, Morgantown, West Virginia.

9. Sabin, S. W. and C. J. Brown. 1962. Analysis of Sale Weights and Growth Rates of Arkansas Milk-Fat Spring Lambs. Ark. Agr. Exp. Sta. Report Series 104.

10. Terrill, C. E. 1961. Improvement Programs For Sheep. USDA Ext. Serv. Report of Proceedings 1961 Livestock Specialist Conference.

11. Winters, L. M., D. L. Dailey, 0. H. Kiser, P. S. Jordan, R. E. Hodgson and W. W. Green. 1946. Factors Affecting Productivity in Breeding Sheep. Minn. Agr. Exp. Sta. Tech. Bull. 174. 




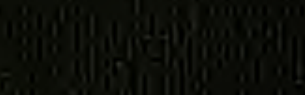

0.1. 